\title{
DZIAŁANIA UNII EUROPEJSKIEJ WOBEC ARMENII PROWADZONE W RAMACH EUROPEJSKIEJ POLITYKI SĄSIEDZTWA I PROGRAMU PARTNERSTWA WSCHODNIEGO
}

\author{
Oksana Voytyuk* \\ THE ACTIVITIES OF THE EUROPEAN UNION \\ TO ARMENIA CARRIED OUT UNDER THE EUROPEAN NEIGH- \\ BORHOOD POLICY AND THE EASTERN PARTNERSHIP

\begin{abstract}
In September 2013, a meeting between the President of Armenia S. Sargsyan and the President of the Russian Federation V. Putin took place in Moscow. During the meeting, the Russian authorities convinced the Armenian President to join the Customs Union and do not proceed further cooperation with the European Union. In the article, the author tries to analyze why Armenia cardinally changed its policy on the eve of the Eastern Partnership Summit in Vilnius on November $28-29^{\text {th }}, 2013$. There are also analyzed the advantages and disadvantages of eventual Armenia's accession to the Customs Union with Belarus, Kazakhstan and Russia, and to the European Union.
\end{abstract}

\section{KEYWORDS}

the European Union, the Customs Union of Belarus, Kazakhstan, and Russia, Armenia, the Eastern Partnership

* Uniwersytet w Białymstoku, Instytut Historii i Nauk Politycznych. 


\section{WPROWADZENIE}

Rozszerzenie Unii Europejskiej (UE) w 2004 oraz 2007 roku spowodowało, że w jej bezpośrednim sąsiedztwie znalazły się państwa obszaru byłego ZSRR, w tym i Kaukaz Południowy. Przyszłość tych państw była nie do końca jasna, ze względu na to, iż z jednej strony interesowała je integracja $z$ UE, a $z$ drugiej trudno było im (z różnych przyczyn) rozerwać więzi z Rosją.

Stosunki byłych republik radzieckich z Moskwą mają specyficzny charakter - w większości przypadków jest to dominacja strony rosyjskiej, która wywiera wpływ na politykę drugiej strony. Pomimo faktu, że od czasu upadku Związku Radzieckiego minęło ponad dwadzieścia lat, skutki niewłaściwej centralnie planowanej gospodarki w większości państw są odczuwalne do dziś. Po pierwsze, widoczna jest zależność energetyczna Białorusi, Mołdawii, Ukrainy, Armenii i do niedawna Gruzji od dostaw gazu ziemnego. Po drugie, głównym rynkiem zbytu towarów produkowanych w wyżej wspomnianych państwach jest rynek rosyjski. Po trzecie, $\mathrm{w}$ wielu państwach istnieją tzw. punkty zapalne w postaci zamrożonych konfliktów - Naddniestrze, Górski Karabach, Osetia Południowa, Adżaria, a w 2014 roku do ich grona dołączyła się Ukraina wraz z aneksją Krymu i wojną na Donbasie.

Unia Europejska, aby zapewnić bezpieczeństwo u swoich wschodnich granic, zaczęła szukać nowych form współpracy i dialogu ze wschodnimi sąsiadami. Konsekwencją rozszerzenia UE stała się Europejska Polityka Sąsiedztwa (EPS), która weszła w życie w 2004 roku. Stanowi ona jakościowo nowy element polityki zewnętrznej UE¹. EPS ma bardzo ważne znaczenie dla UE, ponieważ jej celem jest wzmocnienie stabilności i bezpieczeństwa oraz dobrych relacji pomiędzy państwami członkowskimi UE a krajami z nią sąsiadującymi, zarówno na południu, jak i na wschodzie. Przewiduje również przeciwdziałanie powstawaniu nowych linii podziału między poszerzoną UE a jej sąsiadami². Celem EPS jest także zwiększenie wpływów w europejskiej części obszaru postradzieckiego poprzez zwiększenie wymiany gospodarczej, w tym zabezpieczenia dostaw surowców energetycznych. Unia Europejska w tym kontekście rywalizuje z Rosją, która ma

${ }^{1}$ I. Lyubaszenko, Europejska Polityka Sąsiedztwa Unii Europejskiej wobec państw Europy Wschodniej, Toruń 2012, s. 21.

2 B. Piskorska, Wymiar wschodni polityki Unii Europejsiej, Toruń 2008, s. 155. 
duży wpływ na państwa byłego ZSRR i w oczywisty sposób utrudnia stabilizację sytuacji politycznej na tym obszarze ${ }^{3}$.

W niniejszym artykule koncentruję się na analizie relacji Unia EuropejskaArmenia oraz wyjaśnieniu, dlaczego kraj ten zmienił kierunek polityki zagranicznej na rzecz unii celnej. Szczególna uwaga została poświęcona wydarzeniom, które rozgrywały się w ostatnich miesiącach 2013 roku w Armenii.

\section{WSPÓŁPRACA UNII EUROPEJSKIEJ Z ARMENIĄ}

Współpraca Armenii i UE rozpoczęła pod koniec lat dziewięćdziesiątych XX wieku. W kwietniu 1996 roku zostało podpisane Porozumienie o Partnerstwie i Współpracy, które weszło w życie 1 lipca 1999 roku. W dokumencie zostały określone elementy, na których miała opierać się dwustronna współpraca. Są to m.in.:

- stworzenie odpowiednich ram dla dialogu politycznego między Stronami w celu umożliwienia rozwoju stosunków politycznych;

- wspieranie starań podjętych przez Republikę Armenii dla umocnienia jej demokracji, rozwoju jej gospodarki i zakończenia procesu przechodzenia do gospodarki rynkowej;

- wspieranie wymiany handlowej i inwestycji, jak również harmonijnych stosunków gospodarczych między Stronami sprzyjających trwałemu rozwojowi gospodarczemu;

- stworzenie podstaw współpracy prawnej, gospodarczej, społecznej, finansowej, cywilnej naukowej, technologicznej oraz kulturalnej4.

W czerwcu 2004 roku została wydana Decyzja UE w przedmiocie inkorporacji państw Kaukazu Południowego w struktury Europejskiej Polityki Sąsiedztwa (EPS). Pierwszym krokiem w kierunku wzmocnienia kooperacji było opublikowanie Raportu Krajowego z dnia 2 marca 2005 roku, w którym zarysowano postępy Armenii w prowadzeniu reform politycznych i gospodarczych. W dniu 14 listopada 2006 roku Rada Współpracy UE-Armenia w ramach

3 P. Borkowski, Europejska Polityka Sąsiedztwa - gwiazda jednego sezonu?, [w:] Europejska Polityka Sąsiedztwa, red. J.M. Fiszer, Warszawa 2012, s. 29-40.

${ }^{4}$ Umowa o partnerstwie i wspótpracy między Wspólnotami Europejskimi i ich Państwami Członkowskimi z jednej strony a Republika Armenii z drugiej strony, http://eur-lex.europa.eu/LexUriServ/ LexUriServ.do?uri=CELEX:21999A0909(01):PL:HTML, Dziennik Urzędowy L 239, 09.09.1999, P. 0001-0050, odczyt z dn. 20.01.2014. 
Europejskiej Polityki Sąsiedztwa (EPS) przyjęła pięcioletni Plan Działań dla Armenii. Sformułowano w nim konkretne cele, które miały być osiągnięte w krótko- i średnioterminowej perspektywie. Plan koncentrował się głównie na demokratyzacji, prawach człowieka, reformach społeczno-ekonomicznych, kwestiach energetycznych, redukcji ubóstwa.

Próbą wzmocnienia wschodniego kierunku Europejskiej Polityki Sąsiedztwa miała być polsko-szwedzka inicjatywa powołania programu Partnerstwa Wschodniego. Uruchomienie Partnerstwa Wschodniego nie byłoby możliwe bez zaangażowania Republiki Czeskiej, która uczyniła z niego jeden z priorytetów swojego przewodnictwa w Radzie UE. Program oficjalnie został zainaugurowany 7 maja 2009 roku na szczycie w Pradze, w obecności przedstawicieli wszystkich państw członkowskich UE oraz przedstawicieli państw Europy Wschodniej i Kaukazu Południowego, których dotyczył. Programem Partnerstwa Wschodniego objęto sześć państw obszaru byłego ZSRR: Białoruś, Mołdawię, Ukrainę, Gruzję, Armenię oraz Azerbejdżan ${ }^{5}$. Program Partnerstwa Wschodniego przewiduje ułatwienia $\mathrm{w}$ handlu i wizowe, a w perspektywie także objęcie tych państw ruchem bezwizowym. W Rosji Partnerstwo Wschodnie zostało uznane za antyrosyjską prowokację, wymierzoną przeciwko Kremlowi, przy finansowym wsparciu UE6.

W ciągu ostatnich kilku lat Armenii udało się zrobić postępy na rzecz poprawy kwestii wolności słowa i mediów. Wzmocniona została rola rzecznika obywatelskiego, wprowadzono reformy umacniające instytucje demokratyczne, polegające na dokonaniu podziału władz, zwiększeniu uprawnień zgromadzenia narodowego i wzmocnienia samorządu lokalnego. Wprowadzono środki umacniające niezależność i przejrzystość wymiaru sprawiedliwości, co stanowiło bardzo ważny element reform politycznych. Za istotny krok zmierzający ku poprawie sytuacji państwa można uznać reformę konstytucyjną, która została przeprowadzona w Armenii w listopadzie 2005 roku. Armenia odnotowała również postępy w zakresie poprawy warunków działalności gospodarczej, wprowadzając środki takie jak: uproszczenie procedury rejestracji przedsiębiorstw, obniżenie opłat za zezwolenia i koncesje czy wprowadzenie możliwości rejestracji firmy „w jednym

5 Partnerstwo Wschodnie, http://eastern-partnership.pl/pw_pl/MSZ\%20PW\%20PL.pdf, odczyt $\mathrm{z}$ dn. 20.01.2014.

${ }^{6}$ A. Legucka, Polityka wschodnia Unii Europejskiej, Warszawa 2008, s. 70-72. 
okienku"7. Główną przeszkodą dla rozwoju Armenii w europejskim kierunku pozostaje kwestia Górskiego Karabachu ${ }^{8}$. Postęp w kwestii rozwiązania konfliktu między stronami jest ograniczony.

\section{KWESTIA GÓRSKIEGO KARABACHU}

Za czasów ZSRR Górski Karabach był obwodem autonomicznym w ramach Azerbejdżańskiej SRR, zamieszkanym przede wszystkim przez mniejszość ormiańską, w granicach wytyczonych przez Moskwę w 1923 roku. Po upadku Związku Radzieckiego doszło tam do wznowienia sporu o Górski Karabach, wybuchła wojna, która trwała trzy lata (1991-1994). Konflikt udało się opanować dzięki zaangażowaniu sił rosyjskich, które najpierw wystąpiły po stronie Azerbejdżanu, później jednak przyjęły stronę Armenii. Konflikt zakończył się opanowaniem przez Ormian niemal całego obwodu oraz otaczających go siedmiu rejonów Azerbejdżanu (tzw. terytoria okupowane).

Kwestia Górskiego Karabachu pozostała nierozstrzygnięta, a sam konflikt przeszedł w fazę zamrożenia ${ }^{9}$. Od tego czasu, aby zachować pokój i zapewnić sobie bezpieczeństwo, Armenia stała się głównym sojusznikiem Moskwy na Kaukazie Południowym. Wpływy rosyjskie w Armenii są bardzo silne, mimo że stosunki pomiędzy tymi dwoma państwami nigdy nie były pozbawione napięć. Armenia, spośród trzech kaukaskich republik, jest najbardziej uzależniona od Rosji, zarówno pod względem politycznym (obecność rosyjskich baz wojskowych na terytorium kraju, ma stanowić formę gwarancji bezpieczeństwa na wypadek wznowienia konfliktu karabaskiego), jak i ekonomicznym. W tym ostatnim przypadku zauważyć należy, iż Kreml dąży do przejęcia kontroli nad strategicznymi dziedzinami ormiańskiej gospodarki oraz utrzymania monopolu na dostawy surowców energetycznych do tego kraju ${ }^{10}$.

7 Komunikat Komisji do Parlamentu Europejskiego i Rady-Realizacja Europejskiej Polityki Sasiedztwa w 2007 r., http://eur-lex.europa.eu/LexUriServ/LexUriServ.do?uri=CELEX:52008DC0164:PL:HTML, odczyt z dn. 20.01.2014.

8 P. Marcinkowska, Europejska Polityka Sąsiedztwa, Warszawa 2011, s. 127-129.

${ }^{9}$ Ibidem.

10 M. Falkowski, Polityka Rosji na Kaukazie Południowym i Azji Centralnej, „Prace Ośrodka Studiów Wschodnich" 2006, http://www.osw.waw.pl/sites/default/files/PRACE_23.pdf, odczyt z dn. 20.01.2014, s. 13-16. 


\section{WPŁYW FEDERACJI ROSYJSKIEJ NA POLITYKE ZAGRANICZNA ARMENII}

Rosja z przybliżeniem szczytu Partnerstwa Wschodniego, który odbył się 28-29 listopada 2013 roku w Wilnie, zaczęła wywierać coraz silniejszą presję na byłe republiki radzieckie, aby uniemożliwić podpisanie Porozumienia o Stowarzyszeniu i Wolnym Handlu pomiędzy Ukrainą i UE oraz parafowanie podobnych dokumentów z Mołdawią, Gruzją i Armenią. Aby zapobiec podpisaniu rzeczonych porozumień, strona rosyjska posunęła się do wykorzystania wszelkich możliwych instrumentów szantażu i nacisku na powyżej wymienione państwa. Ukraina była zastraszana przez doradcę Prezydenta Federacji Rosyjskiej S. Glazjewa, który groził jej, że w razie podpisania Umowy Stowarzyszeniowej z UE, utraci własną suwerenność, a stosunki rosyjsko-ukraińskie w sferze politycznej i gospodarczej ulegną znacznemu pogorszeniu. Z kolei Mołdawii wicepremier Federacji Rosyjskiej D. Rogozin groził upokorzeniem ze strony UE, utratą Naddniestrza oraz odcięciem dostępu do rynku rosyjskiego (szczególnie wina mołdawskiego) ${ }^{11}$. Mimo starań, prowadzona przez Kreml polityka wobec Mołdawii i Ukrainy nie przyniosła oczekiwanych rezultatów, państwa te nie odstąpiły z europejskiego kierunku rozwoju. W przypadku Ukrainy ingerencja Rosji w sprawy wewnętrzne kraju doprowadziła do obalenia w lutym 2014 roku reżimu W. Janukowycza, a także poczyniła znaczące zmiany w polityce państwa ukraińskiego (przedterminowe wybory prezydenckie i parlamentarne) i w świadomości jego obywateli. Natomiast w Armenii rosyjski rząd dokonał znacznych postępów, co było ogromnym zaskoczeniem dla UE. Podczas wizyty roboczej w Moskwie prezydent Armenii Serż Sarkisjan oznajmił o decyzji przystąpienia Armenii do Unii Celnej ${ }^{12}$. Wywołało to ogromne rozczarowanie i niezadowolenie społeczne. W kraju pojawiły się protesty.

Zmiana orientacji geopolitycznej Armenii na rzecz przystąpienia do Unii Celnej była podyktowana przede wszystkim motywami politycznymi. Wpływ na zmianę kierunku polityki zagranicznej Armenii miały wydarzenia, które rozegrały się w ciągu ostatnich miesięcy. Pierwszym z nich była realizacja podpisanego dwa lata wcześniej kontraktu na dostawy uzbrojenia przez stronę rosyjską na kwotę w wysokości ponad 1 mld dolarów. Jednak ze względu na

11 В. Кравченко, Дотиснули..., http://gazeta.dt.ua/international/dozhali-armeniya-vstupaet-vtamozhennyy-soyuz-_.html, odczyt z dn. 20.01.2014.

12 Ibidem. 
wzrost napięcia pomiędzy Azerbejdżanem i Armenią realizacja kontraktu na pewien czas była wstrzymana, aby utrzymać równowagę militarną na Kaukazie Południowym ${ }^{13}$.

Po drugie, wpływ na podjęcie decyzji w sprawie przystąpienia do Unii Celnej przez władze w Erewanie miała wizyta W. Putnia w Baku 13 sierpnia 2013 roku. Przybył on tam, aby wyrazić swoje poparcie dla I. Aliewa w październikowych wyborach prezydenckich i jednocześnie chciał pokazać Armenii, że mimo licznych sporów i nieporozumień, jakie miały miejsce, stosunki rosyjsko-azerskie nie są najgorsze ${ }^{14}$.

Po trzecie, zajęcie neutralnej pozycji w kwestii Górskiego Karabachu przez władze rosyjskie zostało umotywowane tym, że strony konfliktu powinny same dojść do porozumienia i próbować rozwiązać istniejący problem. Stanowisko Rosji w tejże kwestii miało być wyraźnym sygnałem dla Armenii, że konsekwencją parafowania przez nią Umowy Stowarzyszeniowej z UE będzie wznowienie konfliktu o Górski Karabach ${ }^{15}$.

Ostatnim wydarzeniem, które przemówiło na korzyść wyboru przez Erewań Unii Celnej było zagrożenie destabilizacją sytuacji wewnętrznej w Armenii z powodu wzrostu aktywności prorosyjskich sił oraz podniesienia cen na gaz ziemny. Ormiańska gospodarska w znaczącym stopniu jest uzależniona od Federacji Rosyjskiej. Większość przedsiębiorstw o znaczeniu strategicznym stanowi w całości lub w części własność rosyjskich kompanii. Erewań jest także w dużym stopniu uzależniony od rosyjskich dostaw gazu ziemnego ${ }^{16}$.

Główną przyczyną, jeśli nie najważniejszą, zmiany polityki zagranicznej Armenii było zapewnienie bezpieczeństwa. Chociażby z tego powodu, że rosyjska „eurazjatycka” integracja oznacza dla Armenii zachowanie status quo ${ }^{17}$. Erewań

13 Rosja i broń za miliard dolarów, http://niezalezna.pl/42534-rosja-i-bron-za-miliard-dolarow, odczyt z dn. 18.06.2013.

14 Путін їде до Алієва за два місяиі до виборів в Азербайджані, http://www.bbc.co.uk/ukrainian/politics/2013/08/130813_putin_baku_visit_az.shtml, odczyt z dn.13.08.2013.

15 С. Навумчик, Вірменія і Митний союз: експерти здивовані, а молодь у депресї, http:// www.radiosvoboda.org/content/article/25095870.html, odczyt z dn. 4.09.2013.

16 В. Кравченко, Дотиснули..., ор.сіt.

17 K. Zasztowt, Armenia między europejskim a eurazjatyckim modelem integracji,„Biuletyn PISM”, nr 36 (1012), https://www.google.com/url?sa=t\&rct=j\&q=\&esrc=s\&source=web\&cd=1\&ved=0CCwQFjAA\&url=http\%3A\%2F\%2Fwww.pism.pl\%2Ffiles\%2F\%3Fid_plik\%3D13335\&ei=bbLSUrT0EueM7QaWh4CoBw\&usg=AFQjCNHIgs33TbyCeOnPLSola7_l1tWKvg, odczyt z dn. 9.04.2013. s. $1-2$. 
obawiał się wznowienia konfliktu o Górski Karabach, w czasie którego w latach 1988-1994 zginęło około 30 tys. osób ${ }^{18}$. Szczególnie, że władze Armenii zdają sobie sprawę, że nie będą w stanie samodzielnie zapobiec eskalacji konfliktu, a potencjał militarny kraju jest dość słaby w porównaniu z potencjałem Azerbejdżanu, który w ciągu ostatnich kilku lat przeszedł gruntowną modernizację. Konsekwencją takiego stanu rzeczy było podjęcie decyzji na rzecz przystąpienia do Unii celnej, co ostatecznie wpłynęło na faktyczne powstrzymanie procesu integracji europejskiej Armenii ${ }^{19}$.

\section{POMIĘDZY UNIĄ CELNĄ A UNIĄ EUROPEJSKĄ. PLUSY I MINUSY DLA ARMENII}

W razie przystąpienia do Unii Celnej Armenia zyskałaby obniżenie cen rosyjskiego gazu, nakłady inwestycyjne na ormiańską infrastrukturę, wzmocnienie sektora energetycznego oraz gwarancje bezpieczeństwa w kwestii karabaskiej. Przeciwko tej formie integracji przemawia zwiększenie zależności politycznej i ekonomicznej od Rosji, podporządkowanie polityki wewnętrznej i zagranicznej Moskwie, co w konsekwencji skutkowałoby częściową utratą suwerenności. W wymiarze wewnętrznym istnieje także ryzyko odejścia od reform politycznych i gospodarczych, które miałyby zbliżyć Armenię do Unii Europejskiej ${ }^{20}$. Decyzja o odejściu od polityki integracji z UE i przystąpienie do Unii Celnej spotkały się z protestami proeuropejsko nastawionej części społeczeństwa, a w szczególności młodzieży ${ }^{21}$.

Znacznie więcej korzyści Armenia odniosłaby w razie parafowania Umowy Stowarzyszeniowej z UE. Byłyby to między innymi: zachowanie suwerenności, zmniejszenie wpływów rosyjskich, odkrycie nowych rynków zbytu dla artykułów ormiańskich, zniesienie taryf celnych, modernizacja gospodarki, dostosowanie

18 Rosja i broń za miliard dolarów..., op.cit.

19 S. Ananicz, Armenia odwraca się od UE, http://www.osw.waw.pl/pl/publikacje/tydzien-nawschodzie/2013-09-04/armenia-odwraca-sie-od-ue, odczyt z dn. 4.09.2013.

${ }^{20}$ Ibidem.

${ }^{21}$ Недоумение и протесты. Армяне настороженно восприняли стремление властей в Таможенный союз, http://korrespondent.net/business/economics/1600067-nedoumenie-i-protesty -armyane-nastorozhenno-vosprinyali-stremlenie-vlastej-v-tamozhennyj-soyuz, odczyt z dn. 5.09.2013. 
ormiańskiej produkcji do wymogów unijnych, handel usługami, wzajemne uznanie dyplomów i kwalifikacji ${ }^{22}$.

Do głównych zagrożeń w sytuacji parafowania porozumienia z UE można byłoby zaliczyć: zagrożenie konfliktem zbrojnym i wsparcie przez Rosję Azerbejdżanu, zmniejszenie eksportu ormaińskich wyrobów do Rosji (jak to było z gruzińskim winem i wodą mineralną), pogorszenie sytuacji ormiańskiej diaspory w Rosji, zmniejszenie liczby transferów pięnieżnych pochodzących z Rosji, wzrost cen na surowce energetyczne ${ }^{23}$.

\section{PRZYCZYNY PORAŻKI EPS W ARMENII}

Wydarzenia, które miały miejsce w ostatnich miesiącach w Armenii, pokazały, że Kreml po raz kolejny potwierdził swoją reputację - mistrza intryg politycznych i manipulacji geopolitycznych. Moskwie udało się umiejętnie wykorzystać lęki i słabości Armenii. Fiasko UE spowodowane było zbyt małym zaangażowaniem w sprawy Armenii. UE nie ukazywała wielkiego zainteresowania tym krajem, nie proponowała alternatywnych możliwości rozwoju elitom politycznym Erewania, nie dawała żadnych gwarancji bezpieczeństwa, na których Ormianom najbardziej zależało. Dlatego też w tej sytuacji, w walce o wpływy w Armenii, zwyciężył Krem²4. Dla UE Armenia nigdy nie była szczególnym przedmiotem zainteresowania. Znalazła się pośród państw Partnerstwa Wschodniego tylko ze względu na Gruzję i Azerbejdżan. Interesy UE w regionie Kaukazu Południowego skupiają się głównie wokół kwestii energetycznych. UE pod tym względem jest bardziej zainteresowana Azerbejdżanem i Gruzją niż Armenią.

Armenia stanęła przed dość trudnym wyborem perspektywy rozwoju demokracji, praw człowieka, społeczeństwa obywatelskiego i innych europejskich wartości lub pozostania w strefie rosyjskich wpływów, ale z gwarancjami bezpieczeństwa. I tak, mając świadomość swojej własnej słabości militarnej, trudnych stosunków sąsiedzkich oraz słabej współpracy i braku większego wsparcia ze strony UE, Armenia wybrała prorosyjski kierunek polityki zagranicznej.

22 Угода про Асоціацію з ЄС проти Митного Союзу. Досліджуємо вигоди, http://img.pravda. com.ua/files/d/c/dc4d0e1-ugoda2.html, odczyt z dn. 20.01.2014..

23 А. Акопян, Судьба Сержа Саргсяна будет отличаться от судьбы Михаила Саакашвили, http://inosmi.ru/sngbaltia/20130807/211670934.html, odczyt z dn. 7.08.2013.

24 Л. Донскіс, Як ЄС втратив Вірменію, http://tyzhden.ua/Columns/50/89152, odczyt z dn. 16.09.2013. 
Zanim jednak nastąpi integracja Armenii z państwami Unii Celnej, Erewan będzie zmuszony zmienić zasady polityki celnej, co będzie wiązało się ze zmianą istniejących dotychczas zobowiązań taryfowych, które Armenia przyjęła, przystępując 5 lutego 2003 roku do Światowej Organizacji Handlu, co może skutkować zażądaniem rekompensaty poniesionych strat przez państwa członkowskie $\mathrm{WTO}^{25}$.

Potwierdzeniem tego, iż decyzja Armenii o przystąpieniu do Unii Celnej jest decyzją stricte polityczną, jest to, że po przystąpieniu do tej organizacji w rozwoju gospodarczym Armenii nie będzie poważnych zmian ${ }^{26}$. Wynika to z tego, że geograficzne położenie kraju nie stanowi strategicznego znaczenia dla Unii Celnej, ponieważ Armenia jest państwem śródlądowym (nie ma dostępu do morza), nie graniczy bezpośrednio z żadnym z państw członkowskich Unii Celnej - Kazachstanem, Białorusią, Rosją.

\section{ZNACZENIE EPS I PARTNERSTWA WSCHODNIEGO DLA ARMENII}

Europejska Polityka Sąsiedztwa (EPS) miała dla Armenii bardzo ważne znaczenie. Erewan wiązał duże nadzieje z uruchomieniem programu Partnerstwa Wschodniego. Jednak EPS nie spełniła oczekiwań państw kaukaskich. W unijnej polityce bezpieczeństwa wobec tego regionu nie było spójności i brakowało długookresowej strategii. Od czasu inauguracji programu Partnerstwa Wschodniego Unia Europejska nie dołożyła zbyt wielu starań, aby wpłynąć na poprawę stosunków przede wszystkim między trzema państwami regionu - Armenią, Gruzją i Azerbejdżanem. Stosunki Armenii z Azerbejdżanem zawsze były napięte ze względu na spór terytorialny o Górski Karabach. Relacje z Gruzją też nie są najlepsze ze względu na silne wpływy rosyjskie w Armenii. Armenia po upadku ZSRR stała się swoistą „forpocztą” Rosji w regionie Kaukazu Południowego ${ }^{27}$. Armenia nie podejmuje żadnych konkretnych działań, aby uwolnić się od wpływów rosyjskich, tak jak to próbują zrobić Azerbejdżan i Gruzja.

Zainteresowanie Erewanu programem Partnerstwa Wschodniego było spowodowane chęcią rozwiązania najważniejszego problemu - sporu teryto-

25 А. Караваєв, Російський експерт: намір Вірменї̈ вступити у Митний союз є суто політичним рішенням, http://tyzhden.ua/News/88517, odczyt z dn. 4.09.2013.

26 В. Матола, Експерт: Вірменія спробує «втекти» від Росії на Захід після розпаду Митного союзу, http://tyzhden.ua/News/88780, odczyt z dn. 7.09.2013.

27 A. Legucka, op.cit., s. 156-157. 
rialnego o Górski Karabach. Wszystkie trzy państwa kaukaskie postrzegają Unię Europejską jako konkurenta Rosji w tym regionie. Każde z państw liczyło na sojusz z UE i pokładało nadzieję na to, iż ta współpraca pomoże rozwiązać im wewnętrzne problemy, charakterystyczne dla tego regionu. Armenia, jak Gruzja i Azerbejdżan, spodziewała się, iż w razie sporu lub konfliktu na Kaukazie Południowym UE opowie się za nią.

Unia Europejska nie dołożyła zbyt wielu starań, aby utrzymać proeuropejskie dążenia Erewanu. Większość inwestycji, które napływały od 2004 roku na Kaukaz Południowy, dotyczyła Gruzji. Ponieważ Azerbejdżan jest postrzegany przez UE głównie jako potencjalny dostawca surowców energetycznych, większość inwestycji zagranicznych, które płynęły na Kaukaz Południowy, dotyczyły rozbudowy infrastruktury energetycznej. Do najważniejszych wspieranych przez UE inicjatyw można zaliczyć budowę ropociągu Baku-Tbilisi-Ceyhan oraz gazociągu Baku-Tbilisi-Erzurum. Obie inwestycje zapewniły drogę dla kaspijskiej ropy i gazu ziemnego na Zachód. Armenia w tej sytuacji została odsunięta na bok. Silne wpływy rosyjskie w tym kraju hamowały współpracę między UE i Armenią. W kwestii karabaskiej zarówno Armenii, jak i Azerbejdżanowi zależało na wyraźnym stanowisku UE w tej sprawie ${ }^{28}$. Obydwie strony uważają, iż aktywność UE w kwestii karabaskiej nie jest wystarczająca ${ }^{29}$.

W chwili obecnej Ormianie są stroną dominującą w konflikcie, to oni są zwycięzcami wojny i kontrolują sporne terytoria, co zawdzięczają Rosji, która początkowo wspierała Baku, a z czasem opowiedziała się po stronie Erewanu ${ }^{30}$. Azerbejdżan jest niezadowolony ze stanu rzeczy i w ostatnich latach zaczął bardzo intensywnie wzmacniać swój potencjał wojskowy. Armenia znalazła się w dość trudnej sytuacji, bez wyraźnego wsparcia ze strony UE w rozwiązaniu kwestii karabaskiej, bez stosunków dyplomatycznych z Azerbejdżanem i Turcją, z napiętymi stosunkami z Gruzją. Taki stan rzeczy sprzyja rozwojowi interesów Rosji w tym regionie. Rosja, korzystając z sytuacji, wzmocniła swoją pozycję w Armenii. Rosjanie uzyskali przedłużenie dzierżawy swoich baz wojskowych

28 Azerbejdżan uważa, iż Górski Karabach jest okupowany przez Armenię, natomiast zdaniem Armenii większość spornego terytorium zamieszkują Ormianie, dlatego ten region powinien należeć do Armenii.

${ }^{29}$ K. Zasztowt, Azerbejdżan po dekadzie rządów prezydenta Ilhama Aliyeva, „Biuletyn PISM”, nr 90 (1066), http://www.pism.pl/Publikacje/Biuletyn/nr-90-1066, odczyt z dn. 4.09.2013, s. 2.

30 A. Jarosiewicz, K. Strachota, Górski Karabach - rozmrażanie konfliktu, http://www.osw.waw.pl/ pl/publikacje/komentarze-osw/2011-10-26/gorski-karabach-rozmrazanie-konfliktu, odczyt z dn. 26.10.2011. 
do 2044 roku, potwierdzili zobowiązania obronne wobec Armenii, ale nie wobec Karabachu, przy jednoczesnej kontynuacji współpracy wojskowej z Azerbejdżanem ${ }^{31}$. Unia Europejska, zamiast aktywniej dążyć do rozwiązania kwestii Górskiego Karabachu, starając się werbalnie sprzyjać rozwiązaniu konfliktu, nie opowiedziała się za żadną ze stron, co osłabiło poparcie inicjatywy EPS i programu Partnerstwa Wschodniego ${ }^{32}$. Obecny impas w procesie pokojowym może doprowadzić do wznowienia wojennej fazy konfliktu. Azerbejdżan coraz bardziej uwalnia się od wpływów rosyjskich. Zamrożony konflikt w Karabachu pozostaje jedynym bezdyskusyjnym instrumentem nacisku Moskwy na Baku. W Azerbejdżanie coraz wyraźniej rysuje się możliwość odzyskania Karabachu drogą wojenną w przypadku niepowodzenia lub przedłużania się procesu pokojowego. Biorąc pod uwagę powyższą sytuację, nietrudno znaleźć odpowiedź na pytanie, dlaczego w przededniu szczytu Partnerstwa Wschodniego w Wilnie (28-29 listopada 2013 roku) Armenia wybrała Unię Celną.

Mimo deklaracji na rzecz przystąpienia do Unii Celnej, Armenia liczy na współpracę z Unią Europejską i ma nadzieje, iż Rosja zmieni swoje zdanie ${ }^{33}$. Niektórzy ormiańscy politolodzy liczą na to, że Armenia będzie uczestniczyła w Unii Celnej w roli obserwatora (według scenariuszu, który początkowo był zaproponowany dla Ukrainy). Jeśli strona rosyjska zgodzi się na udział Armenii w Unii Celnej w roli obserwatora, to perspektywa parafowania, a w przyszłości również podpisania Porozumienia o Stowarzyszeniu między UE i Armenią pozostaje otwarta $^{34}$.

\section{WNIOSKI}

Podsumowując, z pewnością można powiedzieć, iż po upadku ZSRR władze rosyjskie zakładały, że integracja nowych niepodległych państw w przestrzeni poradzieckiej będzie tylko kwestią czasu. Jednak więzi byłych republik radzieckich z Rosją z upływem czasu słabną. Dlatego też od czasu rozszerzenia UE

31 Ibidem.

32 A.Legucka, op.cit., s. 157.

33 В. Матола, op.cit.

34 Росія змусила Вірменію проситися до Митного союзу, озброюючи Азербайджан, -експерт, http://dt.ua/WORLD/rosiya-zmusila-virmeniyu-prositisya-do-mitnogo-soyuzu-ozbroyuyuchi -azerbaydzhan-ekspert-128020_.html, odczyt z dn. 7.09.2013. 
największy nacisk dyplomacja rosyjska kładzie na utrzymanie wpływów w obszarze postradzieckim. Od czasu kiedy granica UE znalazła się w bezpośrednim sąsiedztwie z byłymi republikami radzieckimi, polityka zagraniczna Federacji Rosyjskiej skupiona jest na przeciwdziałaniu aktywności innych państw w strefie jej żywotnych interesów (zachowanie wpływów i kontroli nad obszarem postradzieckim). Dlatego też w interesie Kremla jest, aby Europejska Polityka Sąsiedztwa i program Partnerstwa Wschodniego nie miały na obszarze postradzieckim dużego powodzenia ${ }^{35}$.

Ogólna sytuacja polityczna w Armenii za rządów prezydenta Sarkisjana najprawdopodobniej nie zmieni się. Poprzez odstąpienie od Europejskiej Polityki Sąsiedztwa i programu Partnerstwa Wschodniego Erewan zapewnił sobie gwarancje bezpieczeństwa w razie wznowienia konfliktu z Azerbejdżanem. Poczucie bezpieczeństwa daje również Armenii obecność rosyjskich wojsk w bazie w Giumri. Poza tym po przystąpieniu do Unii celnej polityka zagraniczna i polityka wewnętrzna Armenii jeszcze bardziej zostaną podporządkowana Rosji, a zdolność podjęcia samodzielnych politycznych decyzji znacznie zmaleje. Dotychczasowe postępy, które poczyniła, Armenia współpracując z UE w ramach Europejskiej Polityki Sąsiedztwa i w ramach programu Partnerstwa Wschodniego, mogą zostać zniwelowane. Odejście od zainicjowanych reform politycznych i gospodarczych, nierozstrzygnięta kwestia Górskiego Karabachu oraz zwiększenie wpływu Rosji w przyszłości mogą hamować rozwój Armenii.

Decyzja Armenii w sprawie przystąpienia do Unii Celnej może mieć wpływ na decyzje innych państw objętych programem Partnerstwa Wschodniego, szczególnie Mołdawii i Ukrainy. W Europie Wschodniej toczy się „cicha, nowa, zimna wojna”, w której głównymi graczami są UE i Rosją, a kartą przetargową są wpływy w obszarze poradzieckim. Głównym zagrożeniem tej „wojny” jest to, iż na wschodnich rubieżach UE może powstać nowy „mur berliński”. Obecnie sukces w tejże rywalizacji należy przypisać Rosji, której udało się powstrzymać zbliżenie Armenii do Unii Europejskiej. Kreml nadal będzie podejmować działania, aby do końca przekonać Ukrainę i Mołdawię, aby zrezygnowały ze współpracy z UE i rozpoczęły współpracę w sprawie integracji do Unii Celnej. W Europie Wschodniej rozgrywa się rywalizacja pomiędzy europejskimi i euro-

35 A. Bryc, Europejska Polityka Sąsiedztwa w perspektywie rosyjskiej, [w:] Europejska Polityka Sąsiedztwa, op.cit., s. 128-140. 
azjatyckimi wartościami ${ }^{36}$. Efektywność Europejskiej Polityki Sąsiedztwa w chwili obecnej jest bardzo niska. Aby zachować w przyszłości wpływ na przestrzeni postradzieckiej, Unia Europejska powinna wypracować bardzo konkretne działania dla każdego z państw objętych EPS i Programem Partnerstwa Wschodniego.

36 Война ценностей, http://inosmi.ru/sngbaltia/20130910/212798615.html, odczyt z dn. 10.09.2013. 